\title{
Timothy - the plant and its use on New Zealand farms
}

\author{
J.F.L. CHARLTON ${ }^{1}$ and A.V. STEWART ${ }^{2}$ \\ ${ }^{1}$ Greenfields Communications, Palmerston North \\ ${ }^{2}$ Pyne, Gould, Guinness Limited, Christchurch \\ 'dericpat@ihug.co.nz
}

\begin{abstract}
Timothy is an important pasture species in many cool-temperate regions of the world, particularly those with cold winters and moist summers. In New Zealand, this perennial grass has been used traditionally for mixed pasture in cool moist areas of the southern South Island. It is valued for hay as it retains good feed quality even when seedheads are present. Timothy's flowering and tillering response is different from perennial ryegrass, leading to a high tiller turnover in summer and making it vulnerable to mismanagement, pests and drought. Timothy's inherent digestibility and quality is no greater than perennial ryegrass but because of its late flowering nature, its quality is retained longer in pastures. This, combined with its lack of endophyte and higher clover content, commonly allows a greater animal performance from pastures.

This paper reviews timothy's features and onfarm performance, explains how its features produce its characteristic performance, and considers its potential in current New Zealand grazing systems in different regions.
\end{abstract}

Keywords: grazing, pasture, seeds mixtures, timothy

\section{Introduction}

Timothy (Phleum pratense) is an important perennial grass in many of the world's regions with moist summers and cold winters where it is commonly cut for hay. In New Zealand, it has traditionally been used as a component in seeds mixtures. It is rarely dominant in a pasture so most farmers are unaware of its performance or contribution to their grazing systems. Nonetheless, it is a worthwhile contributor of high quality feed in southern South Island conditions where it is usually included in pasture seeds mixtures (N. Hopkins, I.J. Russell, pers. comm.). In addition, timothy evaluations have often shown improved animal performance over perennial ryegrass pastures (Caradus 1988), including improved milk production in Taranaki (Johnson \& Thomson 1996).
It therefore seems worthwhile to review features and use of this grass, explain how its features produce timothy's characteristic performance, and reconsider its potential in current grazing systems.

\section{The plant}

Timothy originated in Europe but was first valued as pasture grass in the United States. It was widely promoted from 1720 onwards, initially by a farmer named Timothy Hanson - hence its common name.

It is an upright perennial grass with larger leaves than perennial ryegrass, forming a relatively open sward that mixes well with clovers and other species. It has dull, flat, hairless, smooth leaves, swollen tiller bases or corms, and tall "pipe-cleaner" seedheads. Timothy thrives in cool-temperate New Zealand regions and on fertile, heavy soils, rather than summer-dry regions (Levy 1951; Langer 1973).

When compared with the commonly used grasses, such as perennial ryegrass, timothy is late flowering, tending to head 6-10 weeks later than ryegrass. It has less production in winter but commences spring growth early (Hume \& Lucas 1987), giving it a long period with high quality leafy pasture.

Timothy is endophyte free in New Zealand although the endophyte, Epichloe typhina, has been found overseas (Leuchtmann \& Schardl 1998; G.C.M. Latch pers. comm.).

\section{Where timothy grows}

\section{Soils}

Timothy prefers moist soils of moderate to high fertility (Sampson et al. 1951; Langer 1973), a soil pH of 5.57.0 and is only slightly less tolerant of soil aluminium than perennial ryegrass (Wheeler 1995).

\section{Drought tolerance}

Timothy has shallower roots than perennial ryegrass (Garwood 1967) and is more sensitive to drought (Molyneus \& Davies 1983). It is also less tolerant of waterlogging during the growing season than perennial ryegrass or tall fescue (Thomas \& Norris 1979), but will tolerate winter flooding well (Mudd \& Mair 1961). As a consequence, timothy responds well to irrigation in drier regions. 


\section{Shading}

Timothy thrives in partial shade and can even survive heavy shade (Shaw \& Cooper 1973). In shaded conditions, however, its carbohydrate reserves are lower and flowering can be delayed or suppressed (Heide 1994).

\section{How timothy grows}

\section{Establishment}

Timothy is slower to establish than perennial ryegrass, with Stevens et al. (1993) reporting a yield of only $28 \%$ of ryegrass over the first 6 months. Its establishment can be slowed further by low germination when soil temperatures are below $10^{\circ} \mathrm{C}$ (Charlton et al. 1986), and by low seed weights (Jones et al. 1995; Andrews et al. 1997).

\section{Flowering and tillering}

Timothy differs from perennial ryegrass in lacking a winter requirement for flowering (vernalisation), although both require long days (Cooper \& Calder 1964). This difference is crucial to its tillering behaviour and its response to pasture management.

Although autumn-formed tillers behave in a similar way to those of perennial ryegrass, by flowering and subsequently dying off during the next summer, tillers formed by timothy during spring behave differently. In perennial ryegrass these remain vegetative, because their flowering response has not been initiated by winter cold, and a good proportion survive the summer. In timothy however, these tillers will almost all elongate as they initiate flowering, and significantly almost all die during the following summer whether they have actually flowered or not. This means that, unlike perennial ryegrass, almost all timothy's tillers must be replaced during summer, making it vulnerable during this period (Langer 1956, Jewiss 1966).

This high tiller death in summer is a behaviour pattern more similar to annual ryegrass than perennial ryegrass (Jewiss 1966). Timothy's ability to replace tillers during this period is explained by its corms, swellings at the base of its tillers. They act as an important storage organ for carbohydrates, which build up to maximum levels during heading, and decline as new replacement tillers are formed in summer. These corms form during spring on the basal node of each tiller, and enlarge to reach full development at seed maturity. In favourable conditions, secondary corms may be produced in autumn and accumulate carbohydrate reserves critical for winter survival in cold winter climates (Barnard 1964; Evans 1958; White 1973).

Whether spring tillers of timothy develop flowerheads or simply elongate, depends on another unusual mechanism. As temperatures increase during spring and summer, flowerhead development is suppressed. Initially the mechanism reduces flowerhead size, and finally, tillers are formed that lack any flowerhead at all. This mechanism interacts with shading, nutrition, management and genetic origin, and is stronger in northern European material than that from southern Europe (Cooper 1958; Cooper \& Calder 1964; Hay \& Heide 1983; Heide 1994; Langer 1956). Langer (1956) termed these elongated non-flowering tillers "blind tillers" and they cannot be induced to flower by long days, although auxiliary tiller branches can (Cooper 1956). Because they are elongated with an elevated growing point, they show poorer survival under close grazing than those that do not elongate (Stevens et al. 1993).

Often the blind tillers become prostrate, root at the nodes and become stoloniferous, allowing the grass to spread in old pastures (Cooper 1958).

These flowering responses also have important consequences for seed production particularly as spring tillers will frequently have only short seedheads, resulting in lower yields and smaller seed (Langer 1956).

Pasture management of timothy through the spring and summer must be aimed at:

- Building up the carbohydrate reserves before summer, a technique that has been shown to improve post-flowering tiller replacement dramatically in other grasses (Black and Chu 1989, Matthew et al. 1991). The build-up of carbohydrate reserves is reduced under frequent close grazing, shading, and high night temperatures (Pollock \& Jones 1979) all limiting subsequent tiller replacement.

- Maximising growth potential during summer, and minimising stress and pest damage. In particular, pest damage, notably by Argentine stem weevil (Listronotus bonariensis), can be severe during this period (Goldson 1982). Reducing drought stress during summer is also likely to be critical.

\section{Pests and diseases}

Timothy is susceptible to severe attacks from black field cricket (Teleogryllus commodus) (Blank \& Olson 1987), grass grub (Costelytra zealandica) (Farrell \& Sweeney 1974) and Argentine stem weevil despite showing some tolerance of larval mining (Goldson 1982).

More recently, there is evidence that pasture mealy bug (Balanococcus poae) is a problem in Canterbury (Pearson 1989, C. Pennell pers. comm.). In one trial, numbers reached $2219 / \mathrm{m}^{2}$, compared with $854 / \mathrm{m}^{2}$ for endophyte-free perennial ryegrass and $30 / \mathrm{m}^{2}$ for endophyte-infected perennial ryegrass. 
Under regular grazing, diseases are unlikely to be a major problem in New Zealand, but they may be important in hay crops or in autumn-saved pasture. Three diseases are commonly found: leafspot, (Cladosporium phlei $=$ Heterosporium phlei), leaf streak (Cercosporidium graminis $=$ Scolecotrichum graminis = Passalora graminis) and stripe rust (Puccinia striiformis) (Skipp \& Hampton 1996).

\section{Timothy cultivars}

Commercial cultivars are usually hexaploid, with a chromosome number of 42 , but diploid, tetraploid and octoploid forms also occur (Cenci et al. 1984, Neilson and Nath 1961).

Timothy cultivars can be classified according to flowering time, with early cultivars developing seedheads around early December and late cultivars heading around late December. Early-flowering cultivars are usually more erect and less densely tillered than later-flowering ones, with a greater tendency to produce flowerheads in late summer.

\section{Timothy breeding for New Zealand}

Historically, the most outstanding timothy cultivar developed in New Zealand was 'Grasslands Kahu' (Corkill 1949), bred from the cultivars 'S48' and 'S51', both originating from mild coastal areas of Britain, a climate most similar to southern New Zealand. 'S48' from Dorset, and 'S51' from Aberystwyth, Wales (Hall 1948).

Germplasm from mild winter coastal climates is unique amongst timothy cultivars as all other cultivars in the world originate from much colder winter zones requiring superior winter hardiness (Ueda 1990). The excellent adaptation of 'Kahu' is reflected in its consistently superior performance in New Zealand trials, where over 400 lines have been tested over 70 years (Caradus 1978; Corkill 1949; Gorman 1950a; 1950b; Lambert 1950; Maunsell \& Scott 1996; Stevens et al. 1993; Stewart unpublished; K.H. Widdup pers. comm.).

Local ecotypes from Southland are earlier flowering than 'Kahu', but are less productive and persistent in trials. The poorest performers were erect hay-type cultivars bred in colder Northern Hemisphere countries, particularly those from Canada and Scandinavia, some of which are imported and sold here. They have inferior production and persistence, compared with 'Kahu', under New Zealand grazing conditions.

A breeding programme in Gore used recurrent selection within 'Kahu' to develop a cultivar 2 weeks earlier to head, now released as 'Grasslands Charlton' (K.H. Widdup, pers. comm.). This has improved seed yields without losing 'Kahu's' valuable features. Another new early flowering cultivar, 'Ceres Viking', was selected from material collected in 50-year-old pastures in Westland, possibly also of 'S48/S51' origin. This cultivar is finer tillered than 'Kahu' and is likely to better tolerate close sheep grazing.

\section{Future breeding prospects}

Although timothy is used in countries with colder winters and is known for its winter hardiness and lack of drought tolerance, it occurs sporadically at higher altitude in the Mediterranean climatic region despite being absent from the international collections kept by Northern hemisphere breeders (Cenci et al. 1984). The occurrence of timothy in a Mediterranean climate may at first appear unusual but the presence of a corm may be crucial to its survival over the dry summer. The presence of grasses with corms is uncommon outside the Mediterranean (Burns 1946). The performance of such material in the Mediterranean climate regions has been found to be poorer initially, but because of its adaptation and summer dormancy, it gave a greater yield and persistence than Northern European cultivars over 6 years (Bianchi \& Ciriciofolo 1978; Cenci \& Pagiotti 1979; Cenci 1979; Cenci et al. 1984).

In Canterbury, the best Mediterranean material has shown a 20-40\% improvement in cool season growth over 'Kahu' (A.S. Stewart, unpublished data). This opens up the prospect of improving the cool season growth and drought tolerance of timothy in New Zealand.

\section{Pasture quality and animal performance}

Timothy has a good reputation for producing pasture and hay of high feed quality, as well as a good reputation for high palatability, with calves showing a preference for timothy over ryegrass and legumes (Hunt and Hay 1990).

However, a critical look at the literature suggests that its feed quality, like any grass, depends on the flowering stage and growing conditions of the pasture when measurements are made (Mika 1983). When fed at the same digestibility level, perennial ryegrass was superior to timothy, because of a 5-15\% higher voluntary feed intake (Jones 1971; Minson et al. 1964; Miles et al. 1969). This was related to a slower rate of passage and a longer retention time in the gut (Patil 1969), an effect attributed to higher lignin content, and the proportion and composition of timothy's digestible fibre (Walters 1974). Animal performance may be further limited in some situations by timothy's low sodium levels (Jones 1971; Sherrell 1978; Smith et al. 1978; Smith 1981). 
However, despite a lower quality at any given growth stage, timothy pastures frequently provide quality and animal performance advantages over those of perennial ryegrass, and this is largely explained by the following four factors:

- Timothy's later flowering, compared with perennial ryegrass, means that the decline in feed quality associated with seedhead emergence, is delayed, allowing digestibility levels to be maintained from October to December, over a longer period than ryegrass. In liveweight gain studies conducted over this period, animal performance has been found to be superior to perennial ryegrass by $30-60 \%$ (Mclean et al. 1962; Stevens et al. 1993) or over the whole year by $13 \%$ (Davies \& Morgan 1978). Similarly with dairy cows, Johnson \& Thomson (1996) found that timothy gave a 5\% advantage in milk yield, an increased milk fat from 5.26 to $5.36 \%$, and an increase in milk solids from 1.26 to $1.36 \mathrm{~kg} /$ cow/day. These advantages were not apparent in autumn when both pasture species remained leafy (Johnson \& Thomson 1996; McLean et al. 1962).

- Timothy/white clover pastures usually contain up to $50 \%$ more white clover than perennial ryegrass pastures (Anon. 1952; Corkill 1954; Gooding \& Frame 1997; Stevens et al. 1993; Watkin 1975) giving an improved animal performance (Stevens et al. 1992).

- Timothy's decline in feed quality as seedheads develop is less than in perennial ryegrass (Minson et al. 1964) and its reproductive tillers remain green longer and continue to accumulating carbohydrates, even after the seed matures (Pollock \& Jones 1979). Timothy hay, cut at this mature stage, is therefore of superior feed quality to that made from perennial ryegrass.

- As an endophyte-free grass, timothy is superior to endophyte-infected perennial ryegrass pastures, and this difference is more pronounced during summer and autumn, particularly when conditions become dry.

\section{Timothy on the farm}

\section{Regional use}

As the species is at its best on heavier soils in cooler summer areas, and prefers on-off grazing systems to close continuous grazing, timothy is most suitable for southern South Island regions, though it can be selectively used in other regions where the conditions might suit it. Its retention of quality for longer periods than perennial ryegrass may encourage dairy farmers to try it in some North Island regions. It has been included in dairy pasture evaluations at the Dairying Research Corporation's farm in Hamilton (Thom et al. 1999; E.R. Thom, pers. comm.) and since being sown in autumn 1996, has contributed well, especially during 1998, mixed with endophyte-free ryegrass pastures receiving irrigation.

On-farm trials in Canterbury and some other northern South Island areas (T.J. Fraser, pers. comm.) indicate it can be included in mixtures for less stressful grazing systems, when soil conditions encourage its persistence. In Southland, timothy recovers well from heavy grazing and treading pressure during winter, but not in summer.

\section{Grazing management}

Timothy's tillering and flowering behaviour explains why lax rotational grazing is so critical for the persistence of this grass. Its greatest sustainable yield is achieved by leaving a residual sward height of $30-50 \mathrm{~mm}$ (Stevens et al. 1993).

Compared with perennial ryegrass, it is slower to recover from grazing (Gooding \& Frame 1997) and is less tolerant of trampling.

\section{In seed mixtures}

Timothy can be included in most seed mixtures designed for fertile moist pastures, as it is a less aggressive grass component than ryegrasses or cocksfoot. In southern South Island pastures it is usually included when establishing pastures on fertile lowland soils in mixtures with white and/or red clovers, but can also grow compatibly with other perennial legumes, including lucerne and birdsfoot trefoil, and the grazing herbs, chicory and plantain.

Pasture species known to be too aggressive for growing with timothy include Italian ryegrass and dense types of perennial ryegrass, hybrid ryegrass, cocksfoot, and possibly tall fescue. Palatability affects timothy's ability to compete, as it tends to be selectively overgrazed as other pasture grasses decline in quality.

Timothy can be sown in autumn and spring when soil temperatures are above $10^{\circ} \mathrm{C}$ (Charlton et al. 1986) at $3-5 \mathrm{~kg} / \mathrm{ha}$ in a mixture, or at $6-8 \mathrm{~kg} / \mathrm{ha}$ when used as the sole grass. Its poorer competitive ability prevents timothy being used for under-sowing existing pasture.

\section{Conclusion}

Timothy has been an underrated grass that is known to contribute well in many New Zealand pastures. It is recommended as a component of any rotationally grazed pasture on well drained summer-moist soils for farmers seeking to grow high quality pasture feed for producing top quality milk, meat and wool. 


\section{REFERENCES}

Andrews, M.; Douglas, A; Jones, A.V.; Milburn, C.E.; Porter, D.; McKenzie, B.A. 1997. Emergence of temperate pasture grasses from different sowing depths: importance of seed weight, coleoptile plus mesocotyl length and shoot strength. Annals of Applied Biology 130: 549-560.

Anonymous 1952. Experiments in Progress 5. Grassland Research Institute, pp. 23-31.

Barnard, C. 1964. Grasses and Grasslands. McMillan: London. 269 pp.

Bianchi, A.A.; Circiciofolo, E. 1978. Evaluation of the productivity of ecotypes of forage species in Umbria. Annali della Facolta di Agraria, Universita degli Studi di Perugia 32: 143-168.

Black, C.K.; Chu, A.C.P. 1989. Searching for an alternative way to manage Prairie Grass. Proceedings of the New Zealand Grassland Association 50: 219-223.

Blank, R.H.; Olson, M.H. 1987. Screening sixteen pasture species for tolerance to attack by black field cricket (Teleogryllus commodus) New Zealand Journal of Experimental Agriculture 15: 87-90.

Burns, W. 1946. Corm and bulb formation in plants with special reference to Gramineae. Transactions and Proceedings of the Botanical Society of Edinburgh 34: 316-347.

Caradus, J.R. 1978. Performance of timothy cultivars and lines in New Zealand as spaced plants. New Zealand Journal of Experimental Agriculture 6: 11-17.

Caradus, J.R. 1988. Performance of six timothy (Phleum pratense L.) lines in New Zealand in pure swards under grazing. New Zealand Journal of Experimental Agriculture 16: 109-112.

Cenci, C.A. 1979 Evaluation of differently adapted types of Phleum pratense L. Zeitschrift fur Pflanzenzuchtung 85: 148-156.

Cenci, C.A.; Pagiotti, R. 1979. Evaluation of ecotypes of Phleum pratense and Hordeum bulbosum for pastures. Annali della Facolta di Agraria, Universita degli Studi di Perugia 33: 707-726.

Cenci, C.A.; Pegiati, M.T.; Falistocco, E. 1984. Phleum pratense (Gramineae): chromosomal and biometric analysis of Italian populations. Willdenowii 14: 343353.

Charlton, J.F.L.; Hampton, J.G.; Scott, D.J. 1986. Temperature effects on germination of New Zealand herbage grasses. Proceedings of the New Zealand Grassland Association 47: 165-172.

Cooper, J.P. 1956. Phleum. Welsh Plant Breeding Station Report 1950-1956: 40-41.

Cooper, J.P. 1958. The effect of temperature and photoperiod on inflorescence development in strains of timothy (Phleum spp.). Journal of the British Grassland Society 13: 81-91.

Cooper, J.P.; Calder D.M. 1964. The inductive requirement for flowering of some temperate grasses. Journal of the British Grassland Society 19: 6-14.

Corkill, L. 1949. Pasture improvement in New Zealand. Empire Journal of Experimental Agriculture 17: 157-169.

Corkill, L. 1954. Function of pedigree strains of pasture plants. Proceedings of the New Zealand Grassland Association 16: 1-8.

Davies, D.A.; Morgan, T.E.H. 1978. Grazing comparison of four grass species. Welsh Plant Breeding Station Annual Report 1978: 68-69.

Evans, M.W. 1958. Growth and development in certain economic grasses. Agronomy Series No. 147. Wooster, OH: Ohio Agricultural Experiment Station. $112 \mathrm{pp}$.

Farrell, J.A.K.; Sweeney, W.J. 1974. Plant resistance to the grass grub Costelytra zealandica (Coleoptera: Scarabaeidae). II Screening for resistance in grasses. New Zealand Journal of Experimental Agriculture 17: 63-67.

Garwood, E.A. 1967. Some effects of soil water conditions and soil temperature on the roots of grasses. 1. The effects of irrigation on the weight of root material under various swards. Journal of the British Grasslands Society 22: $176-181$.

Goldson, S.L. 1982. An examination of the relationship between Argentine stem weevil (Listronotus bonariensis Kuschell) and several of its host grasses. New Zealand Journal of Agriculture Research 25: 395-403.

Gooding, R.F.; Frame, J. 1997. Effects of continuous sheep stocking at strategic rest periods on the sward characteristics of perennial grass/white clover associations. Grass and Forage Science 52: 350359.

Gorman, L.W. 1950a. Timothy and cocksfoot strain and selection. Proceedings of the New Zealand Grassland Association 12: 79-87.

Gorman, L.W. 1950b. Strains of Timothy (Phleum pratense L). New Zealand Journal of Science and Technology 32. Sec. A: 1-15.

Hall, M. 1948. 500 varieties of herbage and fodder plants. Bulletin 39 of the Commonwealth Bureau of Pastures and Field Crops. CAB.

Hay, R.K.M.; Heide, O.M. 1983. Specific photoperiodic stimulation of dry matter production in a highlatitude cultivar of Poa pratensis. Physiologia Plantarium 57: 135-142.

Heide, O.M. 1994. Control of flowering and reproduction in temperate grasses. New Phytologist 128: 347-362. 
Hume, D.E.; Lucas, R.J. 1987. Effects of winter cutting management on growth and tiller numbers of six grass species. New Zealand Journal of Experimental Agriculture 15: 17-22.

Hunt, W.F.; Hay, R.J.M. 1990. A photographic technique for assessing the pasture species performance of grazing animals. Proceedings of the New Zealand Grassland Association 51: 191-195.

Jewiss, O.R. 1966. Morphological and physiological aspects of growth of grasses during the vegetative phase. In: The growth of cereals and grasses. Eds. Milthorpe, F.L.; Ivins, J.D. Proceedings 12th Easter School in Agricultural Science, University of Nottingham, 1965. Butterworths, London.

Johnson, R.J.; Thomson, N.A. 1996. Effect of pasture species on milk yield and milk composition. Proceedings of the New Zealand Grassland Association 57: 151-15.

Jones, D.I.H. 1971. The chemistry of grass for animal production. Welsh Plant Breeding Station Annual Report 1971: 95-106.

Jones, A.V.; Andrews, M.; Bolstridge, N.; Percival, S. 1995. Emergence of pasture grasses from different sowing depths: importance of coleoptile and mesocotyl width. Proceedings of the Agronomy Society of New Zealand 25: 29-34.

Lambert, J.P. 1950 The Gore Sub-station of the Grasslands Divison. Proceedings of the Agronomy Society of New Zealand 12: 70-78.

Langer, R.H.M. 1956. Growth and nutrition of timothy (Phleum pratense L.). 1. The life history of individual tillers. Annals of Applied Biology 44: 166-197.

Langer, R.H.M. (ed.) 1973. Pastures and pasture plants. Reed, Wellington. 428 pp.

Leuchtmann, A.; Schardl, C.L. 1998. Mating compatibility and phylogenetic relationships among two new species of Epichloe and other congeneric European species. Mycological Research 102: 1169-1182.

Levy, E.B. 1951. Grasslands of New Zealand. Government Printer, Wellington.

Maunsell, L.A.; Scott, D; 1996. Timothy cultivars in a New Zealand high country environment Proceedings of the New Zealand Grassland Association 58: 167170.

Matthew, C.; Chu, A.C.P.; Hodgson, J.; MacKay, A.D. 1991. Early summer pasture control: what suits the plant? Proceedings of the New Zealand Grassland Association 53: 73-77.

Mika, V. 1983. A comparison of the nutritive values of early and late varieties of timothy. Grass and Forage Science 38: 67-71.

Miles, D.G.; Walters, J.K.; Evans, E.M. 1969. Dry matter intake and liveweight gain of cattle and sheep offered different grass varieties with and without clover. Animal Production 11: 19-28.

Minson, D.J.; Harris, C.E.; Raymond, W.F.; Milford, R. 1964. The digestibility and voluntary intake of S22 and H1 ryegrass, S170 tall fescue, S48 timothy, S215 meadow fescue and Germinal cocksfoot. Journal of the British Grasslands Society 19: 298305.

Molyneux, D.E.; Davies, W.J. 1983. Rooting patterns and water relations of three pasture grasses growing in dry soil. Oecologia 58: 220-224.

Mudd, C.H.; Mair, R.B. 1961. Performance of eight seeds mixtures at Great House. 1952-1958 Experimental Husbandry 6: 21-50.

Mclean, J.W.; Thomson, G.G.; Iversen, C.E.; Jagusch, K.T.; Lawson, B.M. 1962. Sheep production and health on pure species pastures. Proceedings of the New Zealand Grassland Association 24: 57-70.

Nielsen, E.L.; Nath, J. 1961. Cytogenetics of a tetraploid form of Phleum pratense L. Euphytica 10: 343350.

Pollock, C.J.; Jones, T. 1979. Seasonal patterns of fructan metabolism in forage grasses. New Phytologist 83: 9-15.

Patil, B.D. 1969. Genetic variation in herbage species with respect to animal performance. Ph. D. thesis, University of Wales (unpublished).

Pearson, W.D. 1989. The pasture mealybug (Balanococcus poae (Maskell)) in Canterbury: A preliminary report. Proceedings of the $5^{\text {th }}$ Australasian Conference on Grassland Invertebrate Ecology: 297303.

Sampson, A.W.; Chase, A; Hedrick, D.W. 1951. California Grasslands and Range Forage Grasses. Bulletin 724: University of California College of Agriculture, California Agricultural Experiment Station, Berkeley, California. 125 pp.

Shaw, A.F.; Cooper, C.S. 1973. The Interagency forage, conservation and wildlife handbook.: Montana State University, Extension Service, Bozeman, Montana. 205 pp.

Sherrell, C.G. 1978. A note on sodium concentrations in New Zealand pasture species. New Zealand Journal of Experimental Agriculture 6: 189-190.

Skipp, R.A.; Hampton, J.G. 1996. Fungal and bacterial diseases of pasture plants in New Zealand. pp. 213236 In: Pasture and Forage Crop Pathology. Eds. Chakraborty, S.; Leath, K.T.; Skipp, R.A.; Pederson, G.A.; Bray, R.A.; Latch, G.C.M.; Nutter, F.W. ASA, CSSA, SSSA. Madison, Wisconsin. Miscellaneous publication.

Smith, G.S.; Middleton, K.R.; Edmonds, A.S. 1978. A classification of pasture and fodder plants according to their ability to translocate sodium from their roots 
into aerial parts. New Zealand Journal of Experimental Agriculture 6: 183-188.

Smith, G.S. 1981. Sodium requirements of farm livestock. New Zealand Journal of Agriculture 142: $21-25$.

Stevens, D.R.; Baxter, G.S.; Casey, M.J.; Miller, K.B.; Lucas, R.J. 1992. A comparison of six grasses for animal production. Proceedings of the New Zealand Grassland Association 54: 147-150.

Stevens, D.R.; Casey, M.J.; Turner, J.D.; Baxter, G.S.; Miller, K.B. 1993. Grasslands Kahu timothy: quality pasture for animal performance. Proceedings of the New Zealand Grassland Association 55: 127-132.

Thom, E.R.; Clark, D.A.; Van Vught, V.T.; Waugh, C.D. 1999. Pasture species and drought impact on yield 1. Milk yield responses in the Waikato. Proceedings of the New Zealand Grassland Association 60: 39-44.
Thomas, H.; Norris, I.B. 1979. Watterlogging. Welsh Plant Breeding Station Annual Report 1979: 146.

Ueda, S. 1990. Timothy Breeding in Japan. Japan Agriculture Research Quarterly 24: 195-201.

Walters, R.J.K. 1974. Variation between grass species and varieties in voluntary intake. General Meeting of the European Grassland Federation 29: 184192.

Watkin, B.R. 1975. The performance of pasture species in Canterbury. Proceedings of the New Zealand Grassland Association 36: 180-190.

Wheeler, D.M. 1995. Relative aluminium tolerance of ten pasture species of Gramineae. Journal of Plant Nutrition 18: 2305-2312.

White, L.M. 1973. Carbohydrate reserves of grasses: a review. Journal of Range Management 26: 13-18. 
